\title{
技術報文
}

\author{
ポリ- - グルタミン酸ナノファイバーによる金属イオンの吸着特性 \\ 京都工芸瀻維大学大学院 工芸科学研究科 田島武治・鋤柄佐千子
}

\section{Sorption Properties of Metal Ions onto Poly- $\gamma$-glutamic Acid Nanofiber}

Takeharu Tajima and Sachiko Sukigara

Department of Advanced Fibro-Science, Kyoto Institute of Technology, Matsugasaki, Sakyo-ku, Kyoto 606-8585, Japan

\begin{abstract}
Poly- $\gamma$-glutamic acid ( $\gamma$-PGA) is a natural polymer that is widely recognized as a component in the viscous filaments of fermented soybean (natto). $\gamma$-PGA is known for its superior biodegradability, biocompatibility, water retention and sorption of metal ions. We used oxazoline component polymer (OXA) for crosslinking agent and prepared $\gamma$-PGA nanofiber from $\gamma$-PGANa by the electrospinning with a non-toxic water solvent system. In this study, we evaluated metal sorption characteristics of $\gamma$-PGA/OXA webs. At low concentration solution of copper ions, the $\gamma$-PGA material dissolved and didn't cohere, but $\gamma$-PGA/OXA webs shrank by the sorption of metal ions, and salt precipitated on its surface. When $\gamma$-PGA/OXA webs contained OXA with a very small or a large quantity, its sorption rate or sorption ability was decreased. A tendency was found to adsorb divalent or trivalent metal ions, and reflect the shrinkage of the $\gamma$-PGA/OXA web.
\end{abstract}

(Received 26 May, 2011 ; Accepted 5 August, 2011)

\section{1. 緒 言}

Poly- $\gamma$-glutamic acid $(\gamma$-PGA)は, 納豆の糸に含まれるポ リアミノ酸で, バチルス属種のような微生物の作用を利 用して生産されるバイオポリマーの一種である[1-3].こ のような非石油由来の素材は低炭素社会の実現に対し注 目が高まっている。 そして, $\gamma$-PGA は生分解性, 生体適 合性, 吸水性, などの特徵を有することから生体材料へ の活用が期待されている $[4,5]$. また特に, $\gamma$-PGA はカル ボキシル基によるイオン交換や分子の螺旋構造への誘導 で金属吸着性を有している[6-10].この性質を利用し, $\gamma$-PGA を用いて水銀や鉛等の人体に障害を引き起こす重 金属, 産業排水系に含まれ廃棄されている金, プラチナ 等の貴金属類を効率よく水中から除去回収することは水 環境の保全及び地球資源の有効活用のために非常に重要 である。これまで, $\gamma$-PGAの架橋ゲルを用いた金属吸着 については, 報告されている $[8,9]$. しかし $\gamma$-PGA と金属 との凝集沈殿物を回収するためにはろ過処理が必要で, 水中から効率良く回収できる方法が求められている。 も し $\gamma$-PGA をナノサイズで繊維化し不織布を作製して用い れば, 吸着後の回収が容易になるとともに比表面積の増 大により吸着効率の向上も期待できる.

$\gamma$-PGAのような天然物の繊維化技術として, 常温湿式 紡糸であるエレクトロスピニングが有望であり，これま で $\gamma$-PGA[11-14]や種々の天然物がエレクトロスピニング
で緎維化されている[15-17]. 一般に $\gamma$-PGAナノファイ バーのエレクトロスピニングには高価, 有害, 危険な有 機酸を溶媒に用いることが多かった. 我々はオキサゾリ ン含有ポリマー(OXA)を架橋剤に用いることで $\gamma$-PGA の $\mathrm{Na}$ 体から有機酸を使用せずに, 大量生産に向いた水系溶 媒でエレクトロスピニングができることを見出し，これ を熱架橋することで吸水性のある水不溶な $\gamma$-PGA/OXA ナ ノファイバー不織布を作製することに成功した[18]. 本 研究では, この $\gamma$-PGA/OXA ナノファイバー不織布を試料 として用い, $\gamma$-PGA が有する金属吸着性について原料の $\gamma$ PGA と比較検討し, その特徴を明らかにする.

\section{2. 実 験}

\section{1 試料}

$\gamma$-PGA は味丹社製の $\gamma$-PGA HM-Na+ form $(\mathrm{Mw} \approx 1.3 \times$ $\left.10^{6} \mathrm{Da}\right)$, 架橋剂は日本触媒(侏社製のオキサゾリン含有ポ リマー(OXA; EPOCROS WS-700, Mw $=4 \times 10^{4}, 25 \mathrm{wt} \%$ 水 溶液, オキサゾリン価 $4.5 \mathrm{mmol} / \mathrm{g}$ )を用いた。 エタノール, 塩酸, 金属塩類 $\left(\mathrm{LiCl}, \mathrm{NaCl}, \mathrm{KCl}, \mathrm{MgCl}_{2} \cdot 6 \mathrm{H}_{2} \mathrm{O}, \mathrm{CaCl}_{2}\right.$ ・ $2 \mathrm{H}_{2} \mathrm{O}, \mathrm{CuCl}_{2} \cdot 2 \mathrm{H}_{2} \mathrm{O}, \mathrm{AlCl}_{3} \cdot 6 \mathrm{H}_{2} \mathrm{O}, \mathrm{ZnCl}_{2}, \mathrm{FeCl}_{3} \cdot 6 \mathrm{H}_{2} \mathrm{O}$, $\mathrm{FeCl}_{2} \cdot 4 \mathrm{H}_{2} \mathrm{O}, \mathrm{MnCl}_{2} \cdot 4 \mathrm{H}_{2} \mathrm{O}$ 及び $\left.\mathrm{CuSO}_{4} \cdot 5 \mathrm{H}_{2} \mathrm{O}\right)$, 水酸化 ナトリウムは関東化学 (株) 社製 JIS 特級を用いた。

$2.2 \gamma$-PGA/OXA ナノファイバー不織布の作製

エレクトロスピニング溶液は $\gamma-\mathrm{PGA}$ と OXA の水溶液 
を固形分比 $\gamma-\mathrm{PGA} / \mathrm{OXA}=99 / 1,96 / 4,90 / 10,60 / 40 \mathrm{wt} \%$ の 配合比 $(\gamma-\mathrm{PGA}$ に対するオキサゾリン価を基にした OXA の $\mathrm{mol}$ 比で $0.007,0.028,0.076,0.45)$ で水/エタノール $/ 1 \mathrm{M}$ 塩酸/固形分 $=45 / 27 / 20 / 8 \mathrm{wt} \%$ に調製し，攪拌溶解した. $\gamma$ PGA と OXA の架橋反応によって得られる $\gamma$-PGA/OXA 架 橋体の分子構造を Fig. 1 に示す.

エレクトロスピニングはエルマルコ社製の NS-LAB200 $\mathrm{S}$ を用い[19], 電極間距離 $130 \mathrm{~mm}$, 電圧 $75 \mathrm{kV}$ で $30{ }^{\circ} \mathrm{C}$, $30 \% \mathrm{RH}$ の雲囲気下で紡糸した. 繊維は $0.1 \mathrm{~m} / \mathrm{min}$ の巻取 り速度で流れるポリプロピレン不織布 $\left(30 \mathrm{~g} / \mathrm{m}^{2}\right)$ の基材に 12 回堆積させた。この不織布を減圧乾燥機で $120^{\circ} \mathrm{C}, 1$ 時間熱架橋処理し, 基材から剥がして目付け $19 \pm 2 \mathrm{~g} / \mathrm{m}^{2}$ の $\gamma$-PGA/OXA 不織布 $(\gamma-\mathrm{PGA} / \mathrm{OXA}=99 / 1,96 / 4,90 / 10,60$ 140wt\%をそれぞれ PGA99, PGA96, PGA90, PGA60 とす る)を作製した。 また， $\gamma$-PGA/OXA $=90 / 10 \mathrm{wt} \%$ で同様に 6 回堆積させ, 目付け $9.3 \pm 2.1 \mathrm{~g} / \mathrm{m}^{2}$ の $\gamma-\mathrm{PGA} / \mathrm{OXA}$ 不織布 (PGA90S)を作製した. また比較として $\gamma$-PGA 原料 (PGAraw) も実験に供した.これら測定に用いた試料の一 覧を Table 1 に示す.

$\gamma$-PGA は水溶性であるため, $\gamma$-PGA/OXA 不織布の水に 対する溶解度を確認した.すなわち $\gamma$-PGA 原料 (PGAraw),

Table $1 \quad \gamma$-PGA samples for metal sorption test.

\begin{tabular}{|c|c|c|c|}
\hline Symbol & $\begin{array}{c}\gamma \text {-PGA:OXA } \\
(w t \%)\end{array}$ & $\begin{array}{l}\text { Weight } \\
\left(\mathrm{g} / \mathrm{m}^{2}\right)\end{array}$ & Experiment \\
\hline PGA99 & $99: 1$ & \multirow{4}{*}{$19 \pm 2$} & \multirow{5}{*}{$\begin{array}{l}\text { Sorption } \\
\text { capacity } \\
\text { for } \mathrm{Cu}^{2+}\end{array}$} \\
\hline PGA96 & $96: 4$ & & \\
\hline PGA90 & $90: 10$ & & \\
\hline PGA60 & $60: 40$ & & \\
\hline PGAraw & 100:0 & - & \\
\hline PGA90s & $90: 10$ & $9.3 \pm 2.1$ & $\begin{array}{l}\text { Shrinkage for } \\
\text { metal ions }\end{array}$ \\
\hline
\end{tabular}

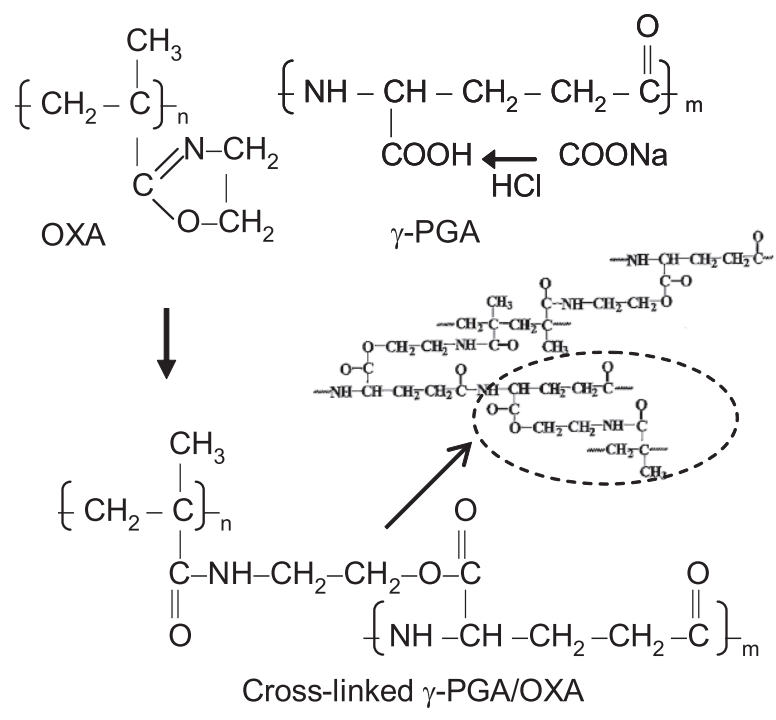

Fig. 1 Molecular structures of $\gamma$-PGA, OXA and Crosslinked $\gamma$-PGA/OXA.
$\gamma$-PGA/OXA 不織布の $20 \mathrm{mg}$ を $20 \mathrm{ml}$ の蒸留水に浸漬, 室 温で 1 時間攪拌後, 水を交換する水洗操作を 3 回繰返し, 不溶分の乾燥重量と処理前との重量から溶解度を式(1)で 求めた。

$$
\text { Weight loss }(\%)=\left\{\left(\mathrm{W}_{0}-\mathrm{W}_{\mathrm{I}}\right) / \mathrm{W}_{0}\right\} \times 100
$$

$\mathrm{W}_{\mathrm{I}}$ は不溶試料重量 $(\mathrm{mg}), \mathrm{W}_{0}$ は初期試料重量 $(\mathrm{mg})$ であ る。

\section{3 銅イオンの吸着性 \\ 2.3.1 銅イオンの吸着試験}

金属イオンは銅イオンを用いた. まず, $\gamma$-PGAのカル ボキシル基のイオン化の影響を把握するため $\mathrm{HCl}, \mathrm{NaOH}$ で pH 2〜10 に調整した水溶液, 及び $\mathrm{pH} 2,4,6,8$ に調 整した $1.0 \mathrm{mmol} / 1$ の $\mathrm{CuCl}_{2} \cdot 2 \mathrm{H}_{2} \mathrm{O}$ を含む溶液各 $10 \mathrm{ml}$ に 30 $\times 30 \mathrm{~mm}$ に採取したPGA90S を投入し, 室温で 10 時間ほ ど攪拌浸漬させた. 浸漬後, それぞれ式(2), 式(3)から 試料の収縮率と吸着率を求めた.

次に, $\gamma$-PGA の添加にともなう銅イオン吸着性を評価 するため $\mathrm{CuCl}_{2} \cdot 2 \mathrm{H}_{2} \mathrm{O}$ を純水に溶解し, $1.0,2.0$ 及び $5.0 \mathrm{mmol} / 1$ の濃度に調製した. これらの溶液各 $10 \mathrm{ml}$ をサ ンプル瓶に採取し, 原料 PGA (PGAraw) 及び PGA/OXA 不 織布(PGA99, PGA96, PGA90, PGA60)を投入後, 室温 で凝集体の変化が十分なくなるように 10 時間ほど覺拌浸 漬させた.この際, 浸漬させる原料 PGA(PGAraw)または PGA/OXA 不織布の量は $3.5,7,15$ 及び $30 \mathrm{mg}$ である.

また, 希釈溶液での吸着性を評価するため銅イオン量 に対する $\gamma-\mathrm{PGA}$ 量を $0.75 \mathrm{~g}[\gamma-\mathrm{PGA}] / \mathrm{mmol}\left[\mathrm{Cu}^{2+}\right]$ の割合で一 定にして $\mathrm{CuCl}_{2}$ 水溶液の濃度を $0.1,0.5,1.0$ 及び $2.0 \mathrm{mmol}$ $/ 1$ に希釈調整した溶液中に各試料, 原料 PGA (PGAraw) 及 びPGA/OXA不織布(PGA99, PGA96, PGA90, PGA60) を浸漬させた. いずれも浸漬後, ICP 発光分光分析装置 (エ スアイアイ・ナノテクノロジー社製 SPS5100)を用いて浸 漬前後の銅イオン濃度から吸着率を式(3)で求めた。 また, 各試料に対する銅イオンの吸着能力を式(4)で求めた.

$$
\text { Shrinkage rate }(\%)=\left\{\left(\mathrm{S}_{\mathrm{i}}-\mathrm{S}_{\mathrm{a}}\right) / \mathrm{S}_{\mathrm{i}}\right\} \times 100
$$

$\mathrm{S}_{\mathrm{i}}, \mathrm{S}_{\mathrm{a}}$ はそれぞれ試料浸漬前, 浸漬後の PGA90S の面積 $\left(\mathrm{mm}^{2}\right)$

$$
\text { Sorption rate }(\%)=\left\{\left(\mathrm{C}_{\mathrm{i}}-\mathrm{C}_{\mathrm{a}}\right) / \mathrm{C}_{\mathrm{i}}\right\} \times 100
$$

$\mathrm{C}_{\mathrm{i}}, \mathrm{C}_{\mathrm{a}}$ はそれぞれ試料浸漬前, 浸漬後の銅イオン濃度 $(\mathrm{mmol} / \mathrm{l})$

$$
\text { Sorption capacity }(\mathrm{mmol} / \mathrm{g})=\left(\mathrm{Q}_{\mathrm{i}}-\mathrm{Q}_{\mathrm{a}}\right) / \mathrm{A}
$$

$\mathrm{Q}_{\mathrm{i}}, \mathrm{Q}_{\mathrm{a}}$ はそれぞれ試料浸漬前, 浸漬後の $\mathrm{CuCl}_{2}$ 水溶液 中の銅イオン量 $(\mathrm{mmol}), \mathrm{A}$ は $\gamma-\mathrm{PGA}$ 試料量 $(\mathrm{g})$ である. 


\subsection{2 銅イオン吸着後の繊維表面観察}

$\gamma$-PGA/OXA 不織布は, 吸着試験後に水洗, 凍結乾燥し て, 緘維形態および集合構造を SEM(KEYENCE 社製，3D Real Surface View Microscope VE-8800，金蒸着あり，印荷 電圧 $5 \mathrm{kV}$, 倍率×1000)で観察した.また, SEM-EDS (SEM : 日立ハイテクノロジーズ社製 S4700, EDS : 堀場製作所社 製エネルギー分散型 $\mathrm{X}$ 線分析器 EMAX) で銅イオンの吸 着状態を観察した.

\section{4 種々の金属イオンによる不織布の収縮性}

濃度を $1.0,2.0,4.0,8.0 \mathrm{mmol} / 1$ の濃度に調製した $\mathrm{CuCl}_{2}$ 水溶液 $10 \mathrm{ml}$ をサンプル瓶に採取し， $30 \times 30 \mathrm{~mm}$ に裁断し たPGA90S を浸漬し，室温で 10 時間攪汼させた。そして 式(4)により吸着能力, 試料の収縮率を(2)式で求めた. 金属イオンの吸着量が試料(PGA90S)の収縮率に及ほすす影 響を明らかにする目的で以下の実験を行った。

$\mathrm{LiCl}, \mathrm{NaCl}, \mathrm{KCl}, \mathrm{MgCl}_{2} \cdot 6 \mathrm{H}_{2} \mathrm{O}, \mathrm{CaCl}_{2} \cdot 2 \mathrm{H}_{2} \mathrm{O}, \mathrm{CuCl}_{2}$. $2 \mathrm{H}_{2} \mathrm{O}, \mathrm{AlCl}_{3} \cdot 6 \mathrm{H}_{2} \mathrm{O}, \quad \mathrm{ZnCl}_{2}, \quad \mathrm{FeCl}_{3} \cdot 6 \mathrm{H}_{2} \mathrm{O}, \mathrm{FeCl}_{2} \cdot 4 \mathrm{H}_{2} \mathrm{O}$, $\mathrm{MnCl}_{2} \cdot 4 \mathrm{H}_{2} \mathrm{O}$ 及び $\mathrm{CuSO}_{4} \cdot 5 \mathrm{H}_{2} \mathrm{O}$ を純水に溶解し，それぞ れ 1.0，5.0，10 mmol/1 の濃度に調製した。また， pHの影 響を比較する Control として, $\mathrm{HCl}, \mathrm{NaOH} て ゙ \mathrm{pH} 2 \sim 10$ の 水溶液を作製した．各 $20 \mathrm{ml}$ をサンプル瓶に採取し， $30 \times$ $30 \mathrm{~mm}$ に裁断した PGA90S の試験片をサンプル瓶に投入 し, 室温で 1 時間浸漬させた. 浸漬前後の試験片の大き さより式(2)から, 試料の収縮率を求めた.

\section{3. 結果および考察}

\section{1 銅イオンの吸着性}

溶液の $\mathrm{pH}$ と吸着率及び収縮率の関係を Fig. 2 に示す. $\mathrm{pH} 2$ では試料 $(\gamma$-PGA90S) に対する吸着性は僅かであるが, $\mathrm{pH} 4$ 以上では吸着性を示し, 試料は青色を呈した。 $\gamma$-PGA のカルボキシル基の $\mathrm{pKa}$ は 4.09 にあり，低い $\mathrm{pH}$ におい て $\mathrm{COOH}$ となり $\gamma$-PGA は水不溶で $\alpha$-helix 構造だが, $\mathrm{pH} 4$ 付近では約 50\%が COOにイオン化され $\mathrm{pH} 6.0$ では完全に $\alpha$-helix から水溶性のランダム-コイル構造に変化すること が知られている $[7,10]$. 本実験の試料 $\gamma$-PGA90Sにおいて は pH4 以上の領域で $\mathrm{COO}$ が銅イオンに配位することで銅 イオンの吸着が生じたと考えられる．Fig.2 に示すように， この時試料の収縮がみられた。 $\mathrm{pH} 2$ では銅イオンの有無 にかかわらず収縮が生じる。しかし $\mathrm{pH} 4$ 以上で，銅イオ ンが吸着した試料と銅イオンの吸着がない試料の収縮率 を比較すると，銅イオンが吸着した試料の方が各 $\mathrm{pH}$ にお いて収縮率が高くなっていることがわかる，すなわち， $\gamma$ PGA/OXA 不織布にみられる収縮は, 銅イオンの吸着によ る寄与が大きいと考えられる。 $\gamma$-PGA では $\mathrm{pH}$ が低下する につれて, 水溶性から水不溶になるが, その $\mathrm{pH}$ に対応し, $\gamma$-PGA/OXA 不織布では, 吸水状態から収縮状態に変化す る. すでに報告している $\gamma$-PGA/OXA 不織布の高湿, 水中 に抢ける伸長試験に扔いて，水を含むことで $\gamma$-PGA/OXA 不織布の弾性率の低下や伸度の増加がみられたことから，
絾維の構造変化が収縮に関係しているのではないかと推 察する.

溶液中の銅イオン量に対する浸漬させた各 PGA 試料量 の割合 $\mathrm{P}\left(\mathrm{g}[\mathrm{PGA}] / \mathrm{mmol}\left[\mathrm{Cu}^{2+}\right]\right)$ と吸着率及び吸着能力の関 係を Fig. 3 に示す. $\gamma$-PGA/OXA 不織布は, OXA の比率に かかわらず $\mathrm{P}$ の増加にともない吸着率が増加し, 試料の 収縮を伴いながら青色を呈した。この青色のものは銅イ オンの吸着に由来するもので, 不織布表面のみならず内 部でも吸着されていることが SEM-EDS の結果でわかる (Fig.4) [20]．そして最大吸着率は, PGA99, PGA96で $\mathrm{P}=$ 約 0.8 , PGA90 で P=約 1.5 に達した後は試料の収縮は見 られず，また，青色も淡くなっている．これ以降 $\mathrm{P} の$ 増 加にともなう吸着率の変化はみられなかった。

$\gamma$-PGA/OXA 不織布に対し, PGAraw は添加量が少ない 場合は凝集し沈殿を生じるが，銅イオン量に対して試料 が過剩 (約 $0.8<\mathrm{P})$ になると白濁，さらには溶解し吸着率は $44 \%$, 吸着能力は $1.5 \mathrm{mmol} / \mathrm{g}$ 程度に留まった. これは $\gamma-\mathrm{PGA}$ は親水性が高く, 凝集性よりも水への溶解性が勝ってい るためである。

Fig. 5 に各 $\gamma$-PGA/OXA 不織布表面の㵶維形態を示す. $\gamma$ PGA 量が多くかつ銅イオン濃度が低い状態 $(\mathrm{P}=3.0)$ では,

PGA99，PGA96は試料がフィルム状になっている，一方 PGA90では繊維形態の痕跡があり, PGA60 は纎維形態を 完全に保っていた。これに対し， $\gamma$-PGA 量が少なく銅イ

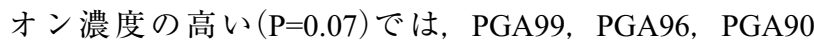
に著しい塩化銅の析出がみられたが，PGA60に変化はみ られなかった。

$\gamma$-PGA/OXA 不織布ならびに $\gamma$-PGA 原料の水に対する溶

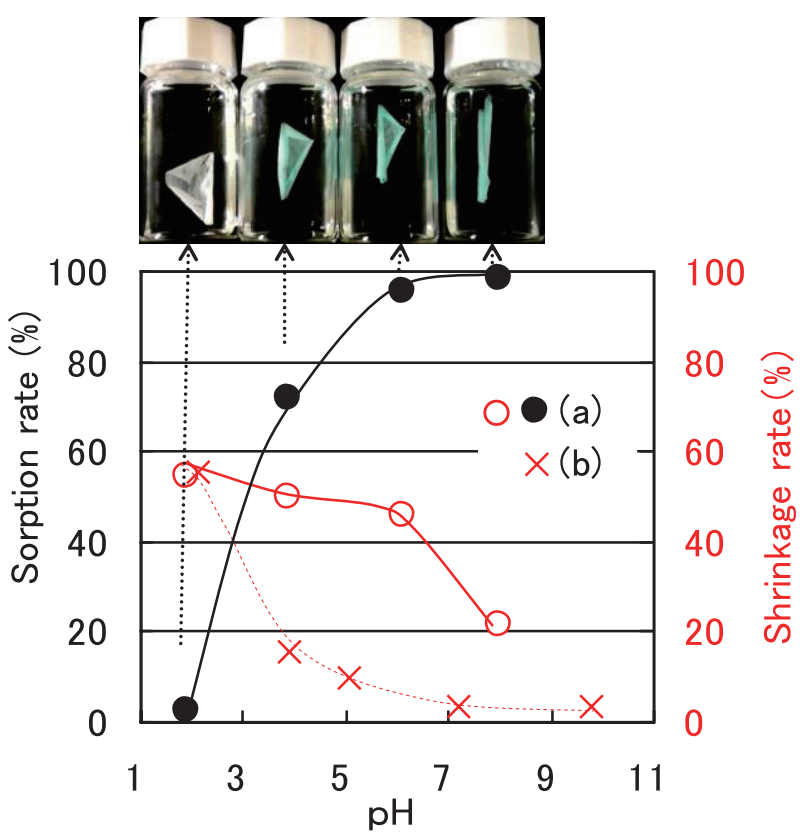

Fig. 2 The effect of $\mathrm{pH}$ on both Shrinkage and sorption rates for $\gamma$-PGA web(PGA90S) after immersion in (a) $1 \mathrm{mM} \mathrm{CuCl}_{2}$ water solution / $\mathbf{0}$; Sorption rate, $\bigcirc$ shrinkage rate , (b) water without $\mathrm{CuCl}_{2}$ / $\times$ shrinkage rate. 
解度と最大吸着率の関係を Fig. 6 に示す. $\gamma$-PGA/OXA 不 織布の最大吸着率は $\gamma$-PGA 原料と比較し高い. 特に PGA 90, PGA60 は 99\% 以上の吸着率を示している. 一方, 水 に対する溶解度が高い PGA99 では最大吸着率が $84 \%$ とや や低く, これは未反応の $\gamma-\mathrm{PGA}$ が溶出していることが考 えられる. 水中でも繊維形態を保持できる試料 PGA96, PGA90, PGA60 の吸着能力を比較すると, PGA96, PGA90 では約 $2.0 \mathrm{mmol} / \mathrm{g}$ であったが, OXA を多く添加し架橋を 進めた PGA60 では, 吸着能力が約 $1.0 \mathrm{mmol} / \mathrm{g}$ と低かった

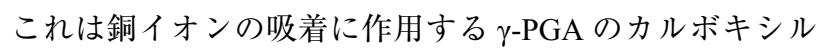
基が OXA との架橋反応に使われてしまっているためと考 えられる.これらのことから, $\gamma-\mathrm{PGA}$ 不織布での銅イオ ンの吸着は, $\gamma$-PGAのカルボキシル基に銅イオンの吸着 がはじまり, それが繊維表面における塩化銅の析出現象 となり繊維形態を保っている不織布の方が, 表面積が大 きくなるために吸着能力が高まったと考えられる [10]. したがって本実験の試料では, OXA を $10 \mathrm{wt} \%$ 配合した $\gamma$ -
PGA/OXA=90/10wt\%が最も好ましいことが判った.

溶液中の銅イオンに対して添加する $\gamma-\mathrm{PGA}$ 試料の量を 一定の割合にしたときの, 銅イオン濃度と吸着能力の関 係を Fig. 7 に示す. いずれの $\gamma$-PGA 不織布も銅イオン濃 度の影響は小さく, 希薄溶液中でも一定の吸着能力 (それ それ $0.7 〜 1.2 \mathrm{mmol} / \mathrm{g})$ を示している. しかし, PGAraw は 低濃度では溶解し吸着能力はみられない.

これらのことから $\gamma$-PGA 原料を吸着剂として見た場合， PGAraw の結果から明らかなように, 水溶液中の銅イオン をより多く吸着させる目的で過剩に添加しても吸着量の 増加はみられない.これに対し, $\gamma$-PGA/OXA 不織布が過 唾に添加された場合, その分は吸着能力に寄与しないが, 溶解しないため一定の吸着率を保持できる.さらに, $\gamma$-PGA /OXA 不織布は凝集物を滤過するような回収プロセスを必 要とせず回収の容易さでも優位な素材形態である.

\section{2 種々の金属イオンの吸着と不織布の収縮}

$\mathrm{CuCl}_{2}$ 水溶液に浸漬した PGA90S の銅イオンの吸着能力
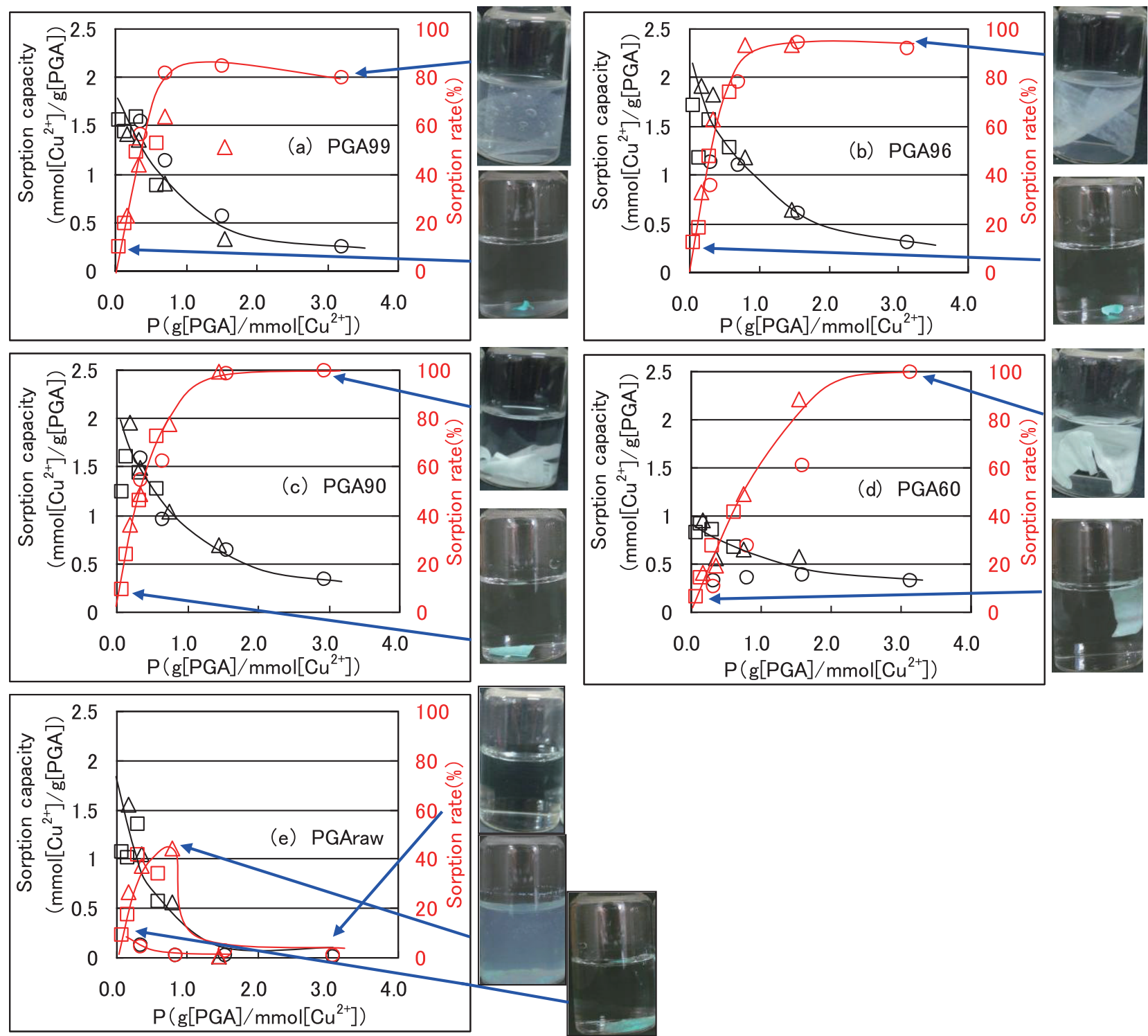

Fig. 3 Sorption of $\mathrm{Cu}^{2+}(\bigcirc 1 \mathrm{mM}, \triangle 2 \mathrm{mM}, \square 5 \mathrm{mM})$ with $\gamma$-PGA/OXA webs and $\gamma$-PGANa ; (a)PGA/OXA =99/1, (b) $=96 / 4,(c)=90 / 10,(d)=60 / 40$ and (e) $=100 / 0 \mathrm{wt} \%$. 


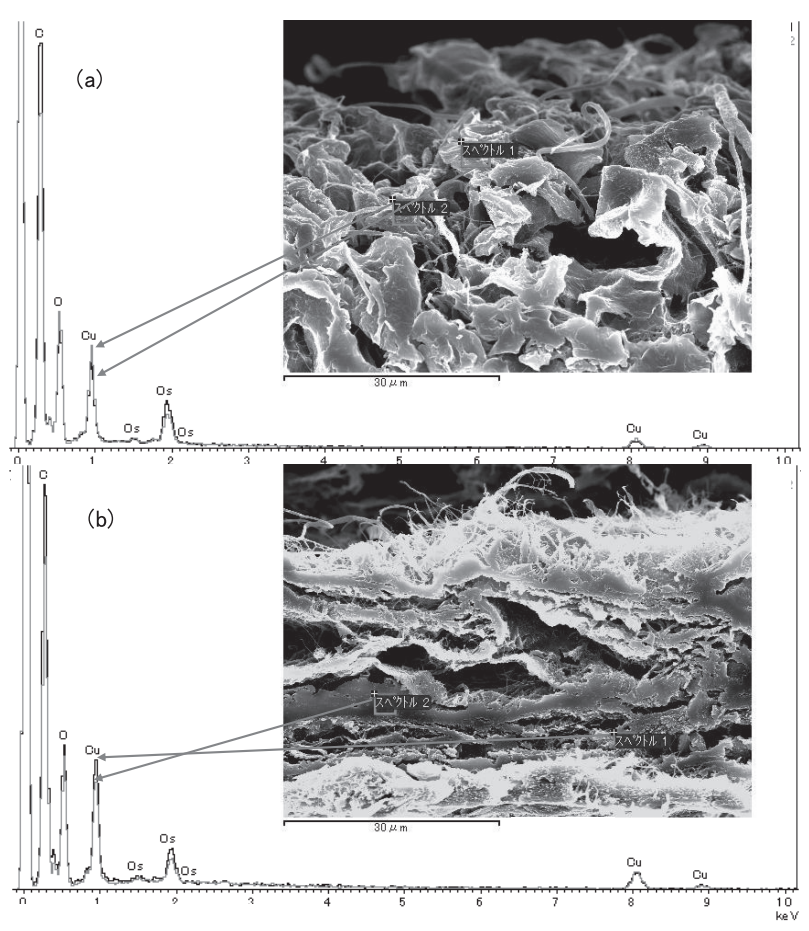

Fig. 4 SEM-EDS of PGA90 after immersion in $\mathrm{CuCl}_{2}$ water solution; (a) surface and (b) cross section.

に対する試料の収縮率の関係を Fig. 8 に示す. $\gamma$-PGA/OXA 不織布 (PGA90S) は銅イオンを吸着するほど大きな収縮を 生じた. 種々の金属イオンに対して, $\gamma$-PGA不織布量に 対する溶液中の金属イオン量 $\mathrm{M}(\mathrm{mmol}[\mathrm{metal}$ ions $] / \mathrm{g}$ $[\mathrm{PGA}])$ と吸着にともない生じた試料の収縮率の関係を Fig.9に示す.すべての金属イオンに対して, 溶液中の金 属イオン量が高いほど収縮が大きい. 金属イオンの錯体 形成, $\gamma$-PGAの高次構造変化, ナノファイバーの絡み合 いなどが関与すると考えられ, この収縮挙動は今後, 詳 細な検討を要するが, 傾向としては 1 価より 2 価, 3 価の 金属イオンの方が収縮率は高い。これら溶液の $\mathrm{pH}$ と収縮 率の関係を調べると, Fig. 10 に示すように金属塩水溶液 では, Control として $\mathrm{HCl}, \mathrm{NaOH} て ゙ \mathrm{pH} 2 〜 10$ に調整した

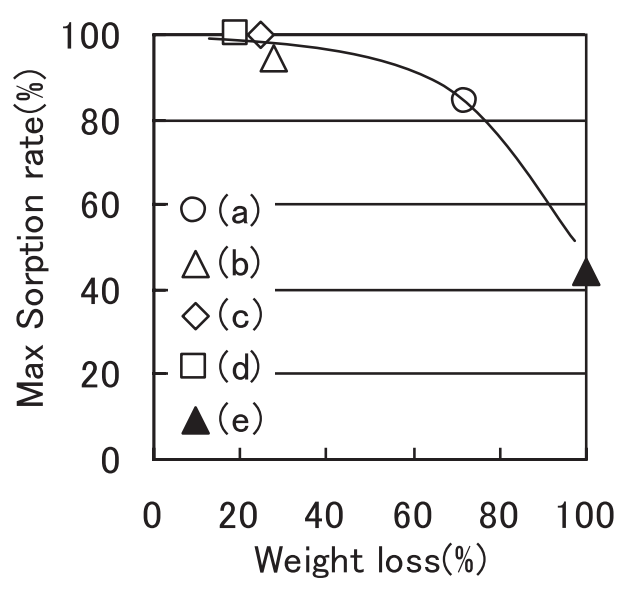

Fig. 6 Relation between Weight loss and Sorption rate ; (a)PGA99, (b)PGA96, (c)PGA90, (d)PGA60 and (e)PGAraw.

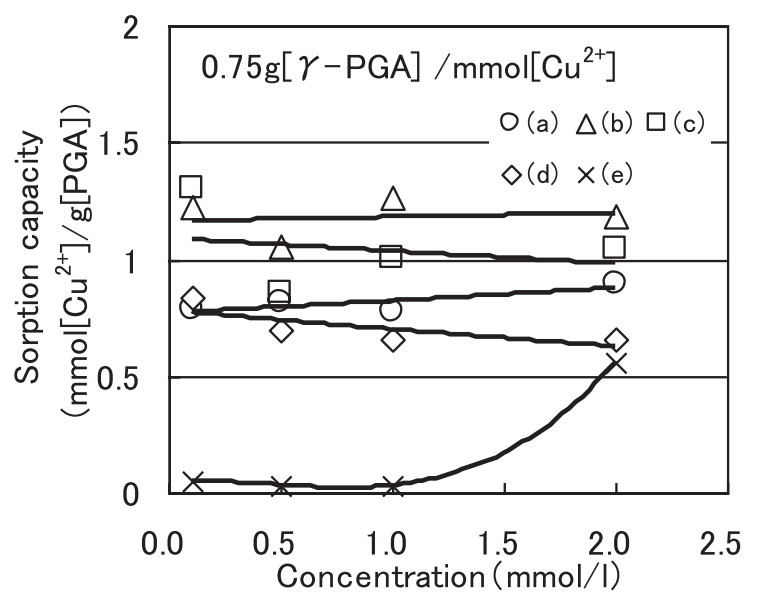

Fig. 7 Relation between concentration of $\mathrm{Cu}^{2+}$ and Sorption capacity at constant rate of $\gamma$-PGA in $\mathrm{Cu}^{2+}$; (a)PGA99, (b)PGA96, (c)PGA90, (d)PGA 60 and (e)PGAraw.

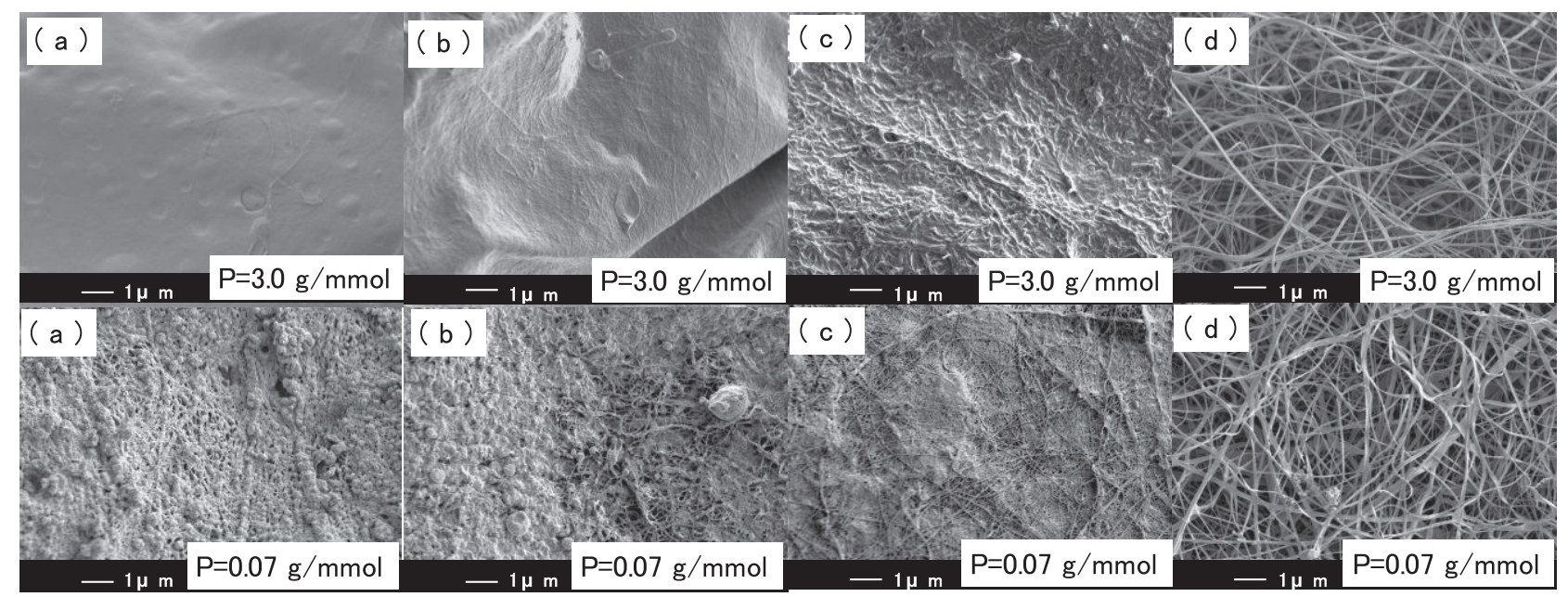

Fig. 5 SEM of $\gamma$-PGA/OXA webs after immersion in $\mathrm{CuCl}_{2}$ water solution ; (a)PGA99, (b)PGA96, (c)PGA90 and (d)PGA60. 


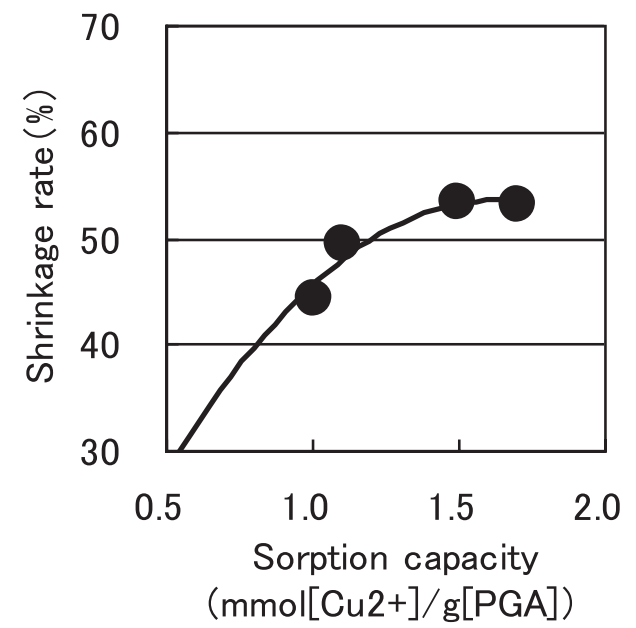

Fig. 8 Relation between sorption capacity and shrinkage rate with PGA90S in $\mathrm{Cu}^{2+}$ ion.

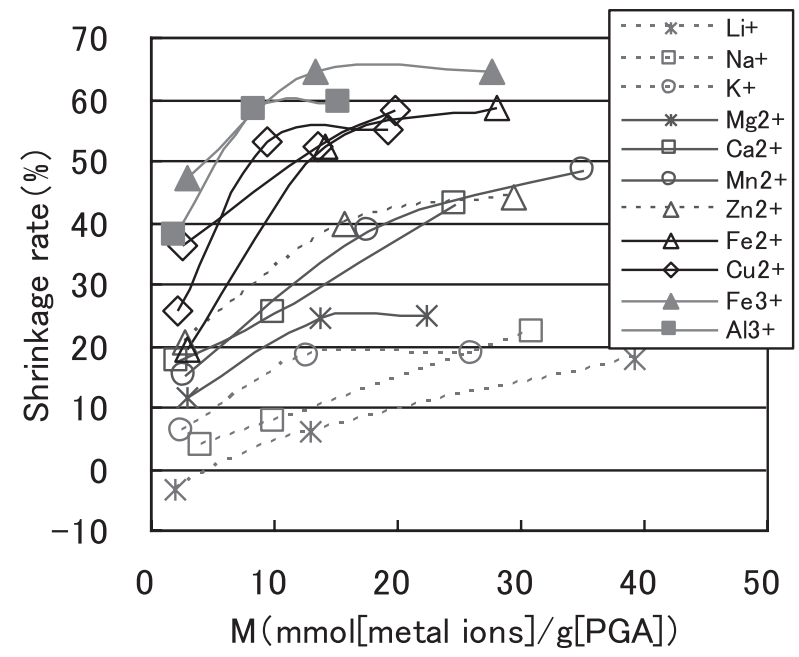

Fig. 9 Sorption characteristics by the shrinkage rate of various metal ions.

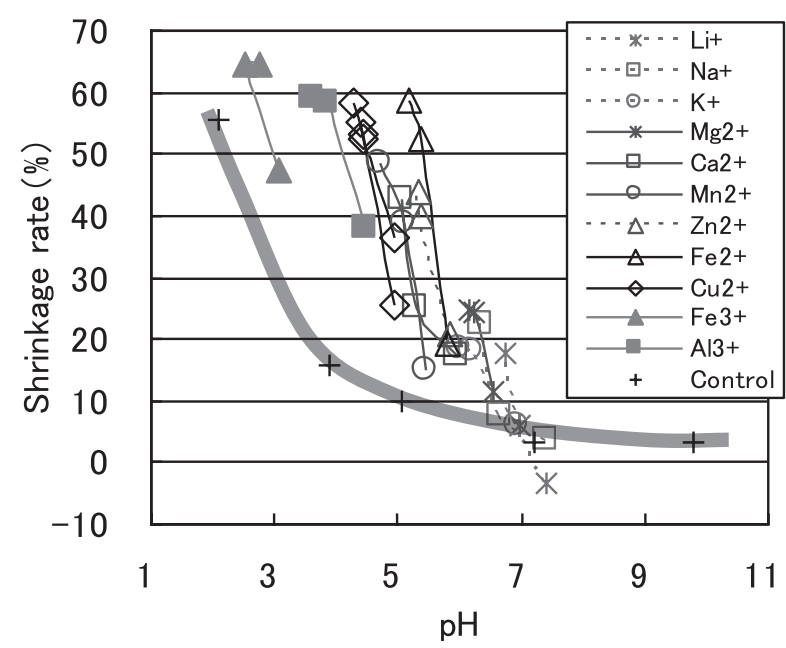

Fig. 10 Relation between $\mathrm{pH}$ of the metal ions water solution and shrinkage rate.
金属イオンを含まない水溶液での収縮率と比較して相当 する $\mathrm{pH}$ での収縮以上に大きな収縮を生じた。これらの収 縮は金属イオンの吸着が影響しているものと推察される.

\section{4. 結 論}

$\gamma$-PGA/OXA 不織布の金属吸着性を原料である $\gamma$-PGA と 比較検討した．塩化銅水溶液を用いた銅イオンの吸着性 は, $\gamma$-PGA 原料が約 $0.8 \mathrm{~g}[\mathrm{PGA}] / \mathrm{mmol}\left[\mathrm{Cu}^{2+}\right]$ 以下では凝集 し沈殿を生じるが, $\gamma-\mathrm{PGA}$ 量がこれ以上または溶液中の 銅イオンが低濃度だと溶解してしまい, 最大吸着率は 44\%, 吸着能力は約 $1.5 \mathrm{mmol} / \mathrm{g}$ であった。 これに対し, 最も高 い吸着特性を示した PGA/OXA = 90/10wt\% (PGA90)では 最大吸着率は $99 \%$, 吸着能力は約 $2 \mathrm{mmol} / \mathrm{g}$ を有した。不 織布表面に塩化銅の凝集析出が確認できた.この PGA/ OXA $=90 / 10 \mathrm{wt} \%$ 不織布は, 溶液中の銅イオン量に応じ, 試料の収縮をともなって吸着能力の増加がみられた. 種々 の金属塩の溶液に対しても, $\gamma$-PGA 不織布は単なる $\mathrm{pH} に$ 依存したカルボキシル基の $\mathrm{COOH}$ 化による構造変化によ る収縮以上に大きな収縮を示し, 特に, 1 価より 2 価, 3 価の金属イオンで収縮が大きく, $\gamma-\mathrm{PGA}$ 不織布がこのよ うな金属イオンを吸着する可能性が伺えた。

$\gamma$-PGA はそのままでは添加量, 回収対象の金属イオン 量, 濃度により凝集しない場合があり使用状況が限定さ れるが, 本研究で用いた $\gamma-P G A / O X A$ 不織布は添加量に応 じた吸着率を保持できる，さらに，凝集体のろ過回収プ ロセスがなくても水中の重金属, 希少金属を効率よく除 去回収できる不織布状であるため, 水質浄化膜等の用途 での新たな素材提案になるものと考えられる.

\section{文 献}

1. M. H. Sung, C. Park, C. J. Kim, H. Poo, K. Soda and M. Ashiuchi, Chem Record, 5, 352 (2005).

2. M. Kunioka, Appl Microbiol Biotechnol, 44, 501 (1995).

3. J. H. Do, H. N. Chang and S. Y. Lee, Biotech Bioeng, 76, 219 (2001).

4. M. Ashiuchi, H. Misono and K. Soda, Expected Materials for the Future, 3(4), 44 (2003).

5. M. Matsusaki and M. Akashi, Kinou Zairyou, 28, 61 (2008).

6. M. Ashiuchi, H. Misono, Biopolymers, 7, 123 (2002).

7. Guan-Huei Ho, Tong-Ing Ho, Kuo-Huang Hsieh, YuanChi Su, Pi-Yao Lin, Jeng Yang, Kun-Hsiang Yang and Shih-Ching Yang, J Chinese Chem. Soc., 53, 1363 (2006).

8. D. Gonzales, K. Fan and M. Sevoian, J Polym Sci Part A : Polym Chem, 34, 2019 (1996).

9. M. Taniguchi, K. Kato, A Shimauchi, X Ping, K. Fuji, T. Tanaka, Y. Tarui and E. Hirasawa. J Biosci Bioeng 99, 130 (2005). 
10. D. Bhattacharyya, J. A. Hestekin, P. Brushaber, L. Cullen, L. G. Bachas, S.K. Sikdar, J Membrane Sci, 141, 121 (1998).

11. H. Yoshida, K. Klinkhammer, M. Matsusaki, M. Möller, D. Klee and M. Akashi, Macromol Biosci, 9, 568 (2009).

12. E. H. Lee, H. Uyama, O. H. Kwon and M. H. Sung, Polym Bull, 63, 735 (2009).

13. K. Ohkawa, Sen-i Gakkaishi, 64, 98 (2008).

14. Y. G. Ko, K. H. Yoon, C. Park, M. H. Sung, O. K. Kwon, C. H. Ahn, Y. J. Kim and O. H. Kwon, Key Eng Mater, 342-343, 225 (2007).
15. J. D. Schiffman and C.L. Schauer, Polymer Reviews, 48, 317 (2008).

16. S. Sukigara, M. Gandhi, J. Ayutsede, M. Micklus and F. Ko, Polymer, 44, 5721 (2003).

17. B. M. Min, S. W. Lee, J. N. Lim, Y. You, T. S. Lee, P. H. Kang and W. H. Park, Polymer, 45, 7137 (2004).

18. T. Tajima, S. Ueno, N. Yabu, S. Sukigara and F.K. Ko, $J$ Appl Polym Sci, DOI : 10.1002/app.34176 (2011).

19. R. Kotek, Polymer Reviews, 48, 221 (2008).

20. Y. Yamashita, Sen'I Gakkaishi, 66, 12, 413-416 (2010). 